\title{
The Effects of Nickel and Cobalt Ions on the Spontaneous Electrical Activity, Slow Wave, in the Circular Muscle of the Guinea-pig Gastric Antrum
}

\author{
Tadao Tomita, Yi-Wei PANG*, and Kayo OGino \\ Division of Smooth Muscle Research, Institute for Comprehensive Medical \\ Science, Fujita Health University, Toyoake 470-11, and Department of \\ Physiology, School of Medicine, Nagoya University*, Nagoya 466, Japan
}

\begin{abstract}
1. Circular muscle strips of the guinea-pig gastric muscle produced spontaneous electrical activity in the form of slow waves. The slow wave amplitude, maximum rate of rise, duration, and frequency were $31 \mathrm{mV}, 60 \mathrm{mV} \mathrm{sec}^{-1}, 4.3 \mathrm{sec}$, and $4.3 \mathrm{~min}^{-1}$ on average, respectively. These parameters were not appreciably affected by $3 \mu \mathrm{M}$ nifedipine or nicardipine, even following membrane depolarization with $60 \mathrm{mM} \mathrm{K}^{+}$.

2. $\mathrm{Ni}^{2+}(1-100 \mu \mathrm{M})$ increased slow wave amplitude and frequency, but reduced the rate of rise, accompanied by membrane depolarization. The rate of rise and depolarization slowly recovered to the control values in the continuous presence of $\mathrm{Ni}^{2+}$, but slow wave frequency remained high. The recovery after wash-out was very poor particularly when a high concentration of $\mathrm{Ni}^{2+}$ was applied.

3. The effects of $\mathrm{Co}^{2+}$ were fundamentally the same as those of $\mathrm{Ni}^{2+}$.

4. Removal of external $\mathrm{Ca}^{2+}$ slowly reduced the rate of rise and amplitude of the slow waves in the absence and the presence of $\mathrm{Ni}^{2+}$ and $\mathrm{Co}^{2+}$, although the effects were reduced in the presence of these metal ions.

5. Concentrations of $\mathrm{Ni}^{2+}$ and $\mathrm{Co}^{2+}$ greater than $1 \mathrm{mM}$ suppressed the slow waves. However, when the external $\mathrm{Na}^{+}$was replaced with $\mathrm{N}$-methyl-D-glucamine during the suppression, nearly normal electrical activity was resumed.

6. Since slow waves were not significantly affected by nifedipine $(3 \mu \mathrm{M})$ and $\mathrm{Ni}^{2+}(100$ $\mu \mathrm{M})$, the inward currents generating slow waves do not seem to flow through L-type $\mathrm{Ca}^{2+}$ channels or typical $\mathrm{T}$-type $\mathrm{Ca}^{2+}$ channels. Slow waves are probably potentiated by $\mathrm{Ni}^{2+}$ and $\mathrm{Co}^{2+}$ acting intracellularly. These ions at higher concentrations seem to inhibit the pacemaker activity more powerfully than they do the inward currents responsible for slow wave generation.
\end{abstract}

Key Words: smooth muscle, nickel, cobalt, slow wave

Correspondence to: Professor Tadao Tomita, Institute for Comprehensive Medical Science, Fujita Health University, Toyoake 470-11, Japan

Phone : 0562-93-2480 ; Fax : 0562-93-1808 : E-mail : ttomita@ fujita-hu.ac.jp 


\section{Introduction}

Gastrointestinal smooth muscle is characterised by the production of spontaneous membrane depolarizations called slow waves, which control the mechanical activity. In the circular muscle of the canine colon (Huizinga, 1991; Sanders, 1992) and guinea-pig stomach (Tomita, 1981) a typical slow wave has an amplitude of $25-35 \mathrm{mV}$, a duration of several seconds and appears at an interval of $10-20$ seconds. Although $\mathrm{Ca}^{2+}$ may play a major role in the rising phase of the slow wave, the ionic mechanisms involved in the membrane depolarization and also in the control of slow wave frequency are still not clear. $\mathrm{Ca}^{2+}$ channel blockers may be used to characterize $\mathrm{Ca}^{2+}$ influx pathways, since dihydropyridines, such as nifedipine, are known to block the L-type $\mathrm{Ca}^{2+}$ channel and $\mathrm{Ni}^{2+}$ to block the $\mathrm{T}$-type $\mathrm{Ca}^{2+}$ channel ( $c f$., Tsien and Tsien, 1990). In canine colonic muscle, nifedipine inhibits mainly a plateau phase of the slow wave, whereas nickel ions $\left(\mathrm{Ni}^{2+}\right)$ mainly inhibit the initial phase (Ward and Sanders, 1992a), and the slow wave is blocked by a combination of $1 \mu \mathrm{M}$ nifedipine and $40 \mu \mathrm{M} \mathrm{Ni}^{2+}$ (Ward and Sanders, 1992b). The authors consider that both phases of the slow wave in this tissue are due to $\mathrm{Ca}^{2+}$ currents through L-type channels and their different sensitivity to nifedipine is explained by the voltage-dependency of channel blockade (Ward and Sanders, 1992b). However, in the same tissue, slow waves persisted in the presence of $21 \mathrm{mM} \mathrm{Na}^{+}$(to abolish the $\mathrm{Na}^{+}$gradient) and nitrendipine (to block L-type channels), but could then be blocked by 1-2 $\mathrm{mM} \mathrm{Ni}^{2+}$ or cadmium ions $\left(\mathrm{Cd}^{2+}\right)$ (Huizinga, Farraway, Den Hertog, 1991), suggesting that the depolarizing phase of the slow wave is due to $\mathrm{Ca}^{2+}$ influx flowing through non-L-type $\mathrm{Ca}^{2+}$ channels.

In the present experiments, using the guinea-pig gastric muscle, the effects of organic (nifedipine and nicardipine) and inorganic $\mathrm{Ca}^{2+}$ channel blockers $\left(\mathrm{Ni}^{2+}\right.$ and $\left.\mathrm{Co}^{2+}\right)$ were investigated to see if the slow waves in the gastric muscle are affected similarly to those in the canine colon. In addition, the effects of these divalent cations were also examined on the membrane depolarization caused by removal of sodium ion $\left(\mathrm{Na}^{+}\right)$, ionic mechanism of which is also not known (Tomita and Pang, 1996).

\section{Methods}

The methods were similar to those previously described (Tsugeno, Huang, Pang, Chowdhury and Tomita, 1995). The guinea-pigs (300-350 g) were killed by stunning and bleeding, and the stomach excised. After removal of the mucosa, muscle strips $(2 \times 7 \mathrm{~mm})$ were dissected from the antral region in the direction of the circular muscle, and the longitudinal muscle layer was carefully stripped off using a pair of fine forceps. One end of a muscle strip, which was reduced to $1 \times 5 \mathrm{~mm}$, was tied by a silk thread to a small piece of artificial rubber, fixed to the bottom of a small chamber $(0.2 \mathrm{ml})$ by small pins, and the other end of the strip was connected to a strain gauge with a fine thread to record tension development.

The membrane potential was measured using the conventional intracellular microelectrode technique. Electrodes were inserted from the side facing the longitudinal muscle layer. The chamber was perfused with a physiological solution, prewarmed to $35^{\circ} \mathrm{C}$ and equilibrated with

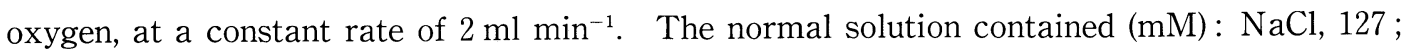


$\mathrm{KHCO}_{3}, 6 ; \mathrm{CaCl}_{2}, 2.4 ; \mathrm{MgCl}_{2}, 1.2$; glucose, 12 ; HEPES, 10 (pH adjusted to 7.4 at $35^{\circ} \mathrm{C}$ with $\mathrm{NaOH}$ ). When the external $\mathrm{K}^{+}$was increased, or $\mathrm{Na}^{+}$or $\mathrm{Cl}^{-}$were reduced, $\mathrm{NaCl}$ was replaced with equimolar $\mathrm{KCl}, \mathrm{N}$-methyl-D-glucamine ( $\mathrm{NMDG}$, $\mathrm{pH}$ being adjusted by $\mathrm{HCl}$ ), or $\mathrm{Na}$ isethionate, respectively. Atropine $(1 \mu \mathrm{M})$, indomethacin $(1 \mu \mathrm{M})$ and nitro-L-arginine methylester $(50 \mu \mathrm{M})$ were added to the perfusate throughout experiments to inhibit possible contributions of endogenous acetylcholine, prostaglandins and nitric oxide, respectively. The drugs used were all obtained from Sigma (St Louis, USA). The numeral data are expressed as means \pm S.E.M. with the number of observations (n).

\section{Results}

\section{Effects of nifedipine and nicardipine}

The configuration and frequency of slow waves in the circular muscle of guinea-pig gastric antrum varied to some degree in different preparations. A typical slow wave consisted of an initial transient depolarization and a following slow depolarizing phase, but the separation of these phases were poor in some preparations. The peak slow wave amplitude was $31 \pm 2.5 \mathrm{mV}$, the frequency was $4.3 \pm 0.5 \mathrm{~min}^{-1}$, and the most negative membrane potential between slow waves was $-63.1 \pm 1.1 \mathrm{mV}(n=32)$. The maximum rate of rise and the duration of the slow wave at a half amplitude were $59.5 \pm 20 \mathrm{mV} \mathrm{sec}^{-1}$ (range : $37-92 \mathrm{mV} \mathrm{sec}^{-1}$ ) and $4.3 \pm 0.6 \mathrm{sec}$
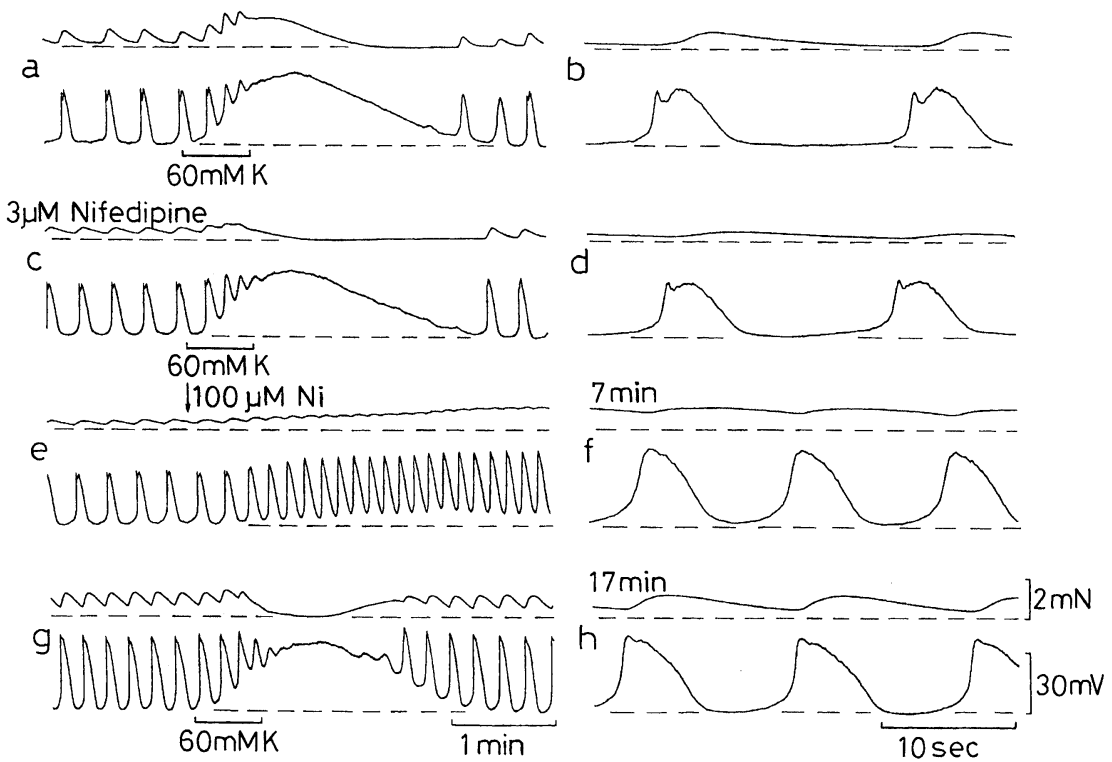

Fig. 1. Effects of nifedipine and $\mathrm{Ni}^{2+}$ on spontaneous electrical slow wave activity (lower) and contraction (upper trace) in a circular muscle strip of the guinea-pig gastric antrum. a : $40 \mathrm{sec}$ application of $60 \mathrm{mM} \mathrm{K}$, as shown below the trace, before and $\mathrm{c}: 10 \mathrm{~min}$ after continuous application of nifedipine $(3 \mu \mathrm{M})$. e: At the arrow $100 \mu \mathrm{M} \mathrm{Ni}^{2+}$ was applied continuously; g: $60 \mathrm{mM} \mathrm{K}{ }^{+}$was applied 10 min after $\mathrm{Ni}^{2+}$, in the presence of nifedipine. On the right,, slow waves are shown at 8 times faster recording speed $(\mathrm{b}:$ control; $\mathrm{d}: 8$ min after $60 \mathrm{mM} \mathrm{K}^{+}$treatment in the presence of nifedipine; $\mathrm{f}: 7 \mathrm{~min}$ after $; \mathrm{h}: 17 \mathrm{~min}$ after $\mathrm{Ni}^{2+}$ application). Records from the same cell. 
(range : $3.3-5.1 \mathrm{sec})$ respectively $(n=15)$.

Nifedipine $(3 \mu \mathrm{M})$ had no significant effect on the slow waves even after more than $10 \mathrm{~min}$ treatment and after depolarization produced by $60 \mathrm{mM} \mathrm{K}^{+}$in the presence of nifedipine, although it reduced tension development caused by the slow waves and by $60 \mathrm{mM} \mathrm{K}^{+}$(Fig. 1). These results were confirmed in 6 muscle strips. Since the inhibition of $\mathrm{K}^{+}$-induced contracture and of slow wave-evoked contraction did not recover after nifedipine had been removed for more than $30 \mathrm{~min}$, nifedipine-sensitive $\mathrm{Ca}^{2+}$ channels were considered to remain blocked. Similar results were also obtained with nicardipine $(1 \mu \mathrm{M})$ in 5 strips.

\section{Effects of $\mathrm{Ni}^{2+}$}

$\mathrm{Ni}^{2+}$ increased the amplitude and frequency of the slow waves and reduced their rate of rise concentration-dependently between 1-100 $\mu \mathrm{M}$. This was accompanied by membrane depolarization and an increase in muscle tone, but the depolarization and also the reduced rate of rise were transient. Fig. 1 shows typical effects of $100 \mu \mathrm{M} \mathrm{Ni}^{2+}$ in the presence of nifedipine $(3 \mu \mathrm{M})$. Both membrane potential and rate of rise slowly recovered to nearly the control value in the continued presence of $\mathrm{Ni}^{2+}$ and nifedipine (the maximum rate of rise was $47 \mathrm{mV} \mathrm{sec}^{-1}$ before $\mathrm{Ni}^{2+}$ application, 20,33, and $59 \mathrm{mV} \mathrm{sec}^{-1}$ at 3,7 , and $17 \mathrm{~min}$ after $\mathrm{Ni}^{2+}$, respectively). The slow wave amplitude and frequency remained higher than the control even after 25 min in the presence of $\mathrm{Ni}^{2+}$. Recovery was incomplete for 15-20 min after $\mathrm{Ni}^{2+}$ washout. The $\mathrm{Ni}^{2+}-$ induced depolarization was only observed in response to the first application. Even when $\mathrm{Ni}^{2+}$
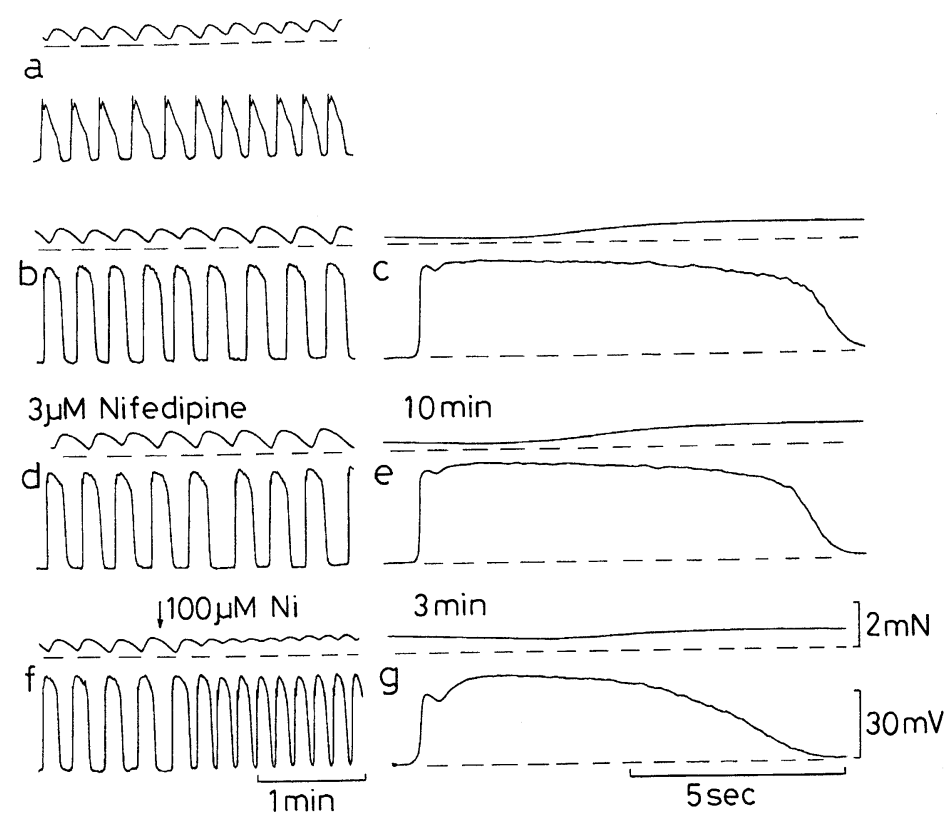

Fig. 2. Effects of nifedipine $(3 \mu \mathrm{M})$ and $\mathrm{Ni}^{2+}(100 \mu \mathrm{M})$ on slow wave of the square type. a : typical slow wave; b, c: square wave type potentials recorded from the same cell, but different from (a). $a$ and $b$ : in the absence of nifedipine: $d: 10$ min after nifedipine (3 $\mu \mathrm{M}) ; \mathrm{f}: \mathrm{Ni}^{2+}$ application in the presence of nifedipine. $\mathrm{c}$, e, and $\mathrm{g}$ were recorded at a faster speed at the end of traces $b, d$, and $f$, respectively. 
was reapplied at an interval of more than 30 min no clear depolarization was produced by the second application. Therefore, the mechanism underlying this depolarization was difficult to analyse.

Very rarely, slow waves of a large square type were recorded. In the experiment shown in Fig. 2, slow waves with a shoulder were recorded at first (a); this type of configuration has often been observed with the sucrose-gap method (Ohba, Sakamoto and Tomita, 1977). At the end of record (a), the electrode was reinserted into another cell from which large $(42 \mathrm{mV})$ square slow waves were recorded (b). Judging from their duration these potentials appear to correspond to the lower component of the slow waves shown in (a). Similar slow waves were observed in the rabbit small intestine (Taylor, Daniel and Tomita, 1976). The maximum rate of rise was approximately $1 \mathrm{~V} \mathrm{sec}^{-1}$ which was more than 10 times faster than that of ordinary slow waves. Nifedipine had no clear effect on either the square slow waves or the contractions in this preparation $(\mathrm{d}, \mathrm{e}) . \quad \mathrm{Ni}^{2+}(100 \mu \mathrm{M})$ in the presence of nifedipine shortened the duration of the upper part and increased the frequency of the slow waves, but did not increase their amplitude (f, g). The amplitude of the initial part of the depolarization was slightly reduced by $\mathrm{Ni}^{2+}$ so that a notch appeared between the initial and later phase $(\mathrm{g})$, as generally observed for a more typical slow wave. The maximum rate of rise was reduced to $400 \mathrm{mV} \mathrm{sec}{ }^{-1} 5 \mathrm{~min}$ after $\mathrm{Ni}^{2+}$ application, but no further study was possible because of a failure to keep the penetration.

\section{Effects of $\mathrm{Co}^{2+}$}

The effects of $\mathrm{Co}^{2+}$ were similar to those of $\mathrm{Ni}^{2+}$. Fig. 3 shows typical effects of $30 \mu \mathrm{M}$ $\mathrm{Co}^{2+}$ in the presence of nifedipine $(3 \mu \mathrm{M}) \cdot \mathrm{Co}^{2+}$ depolarized the membrane (accompanied by raised muscle tone), increased the amplitude and frequency of the slow waves, and abolished the separation between the initial spike and late slow component (c). The membrane potential between slow waves slowly recovered in the continuous presence of $\mathrm{Co}^{2+}$ and nifedipine and the
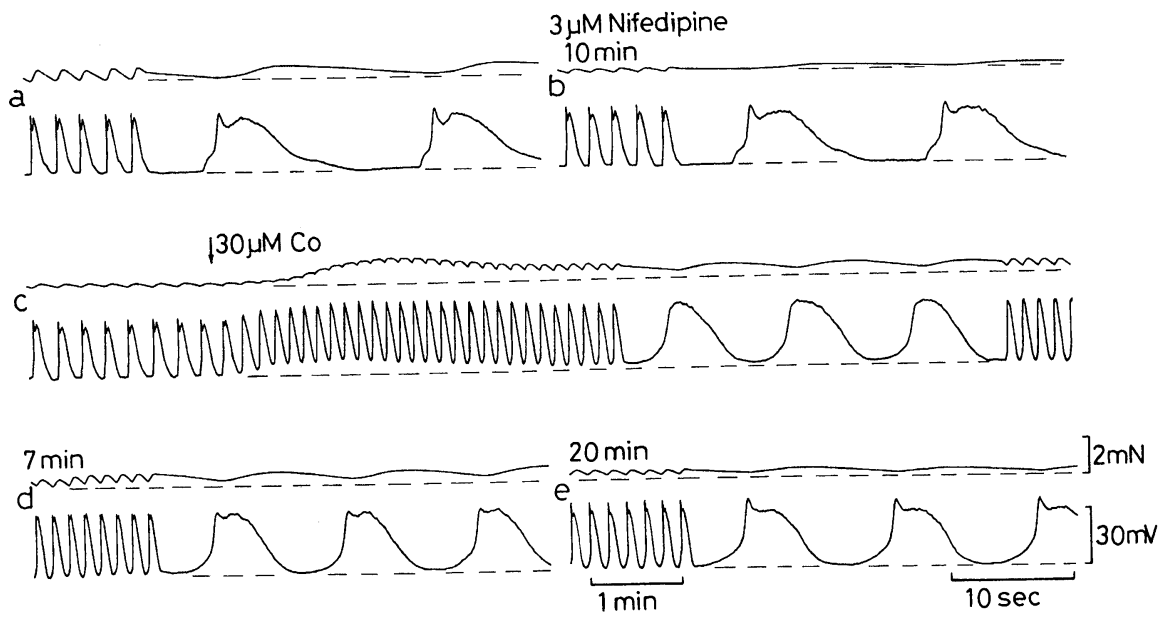

Fig. 3. Effects of nifedipine $(3 \mu \mathrm{M})$ and $\mathrm{Co}^{2+}(30 \mu \mathrm{M})$, recorded at slow and fast speed, a similar experiment to Fig. 1. At the arrow in $\mathrm{c}, \mathrm{Co}^{2+}$ was applied in the presence of nifedipine and both were present throughout the remaining traces. $\mathrm{d}$ and e: 7 and $20 \mathrm{~min}$ after $\mathrm{Co}^{2+}$ application. Continuous records from the same cell. 
initial spike component developed again $(\mathrm{d}, \mathrm{e}) \cdot \mathrm{Co}^{2+}$ reduced the rate of rise of the slow wave initially (from $70 \mathrm{mV} \mathrm{sec}^{-1}$ to $42 \mathrm{mV} \mathrm{sec}^{-1}$ at $5 \mathrm{~min}$ ), but as the spike component developed the rate of rise increased again $\left(64 \mathrm{mV} \mathrm{sec}^{-1}\right.$ at $10 \mathrm{~min}$ and $67 \mathrm{mV} \mathrm{sec}^{-1}$ at $20 \mathrm{~min}$ ), approaching the control value.

\section{Irreversible effects of $\mathrm{Co}^{2+}$ and $\mathrm{Ni}^{2+}$}

$\mathrm{Ni}^{2+}$ and $\mathrm{Co}^{2+}$ were effective at $1 \mu \mathrm{M}$. The effects were clearer when the frequency was slow or irregular before application. Low concentrations of these ions (1-10 $\mu \mathrm{M})$ did not depolarize the membrane significantly, but increased the frequency of the slow waves, and increased their regularity, as shown in Fig. 4a. The effect remained after removal of $\mathrm{Co}^{2+}$ (or $\mathrm{Ni}^{2+}$ ) for more than $10 \mathrm{~min}$, but a short treatment with $2 \mathrm{mM}$ EDTA (ethylenediamine tetraacetic acid) abolished the effects of these ions and in the example shown in Fig. $4 \mathrm{~b}$ the frequency reverted to its original irregularity. When a concentration of higher than $100 \mu \mathrm{M}$ was applied, the effects were nearly irreversible, even after a 1-2 min treatment with $2 \mathrm{mM}$ EDTA (not shown). When the concentration of $\mathrm{Ni}^{2+}$ or $\mathrm{Co}^{2+}$ was higher than $10 \mu \mathrm{M}$, the membrane was depolarized, but although there was some concentration dependency of the depolarization, its degree varied in different preparations. Fig. 5 shows the largest depolarization produced by $100 \mu \mathrm{M} \mathrm{Co}^{2+}$. In this experiment nifedipine was not added, but the degree of depolarization varied significantly in different preparations even in the presence of $1 \mu \mathrm{M}$ nifedipine. The slow waves disappeared when the membrane was strongly depolarized by these divalent cations, as shown in Fig. 5a, but the depolarizations slowly subsided and rhythmic acitivty gradually reappeared during the continued presence of the cations (see Fig. 5b, c). At concentrations higher than $30 \mu \mathrm{M}$, the effects of these cations remained after wash-out and a

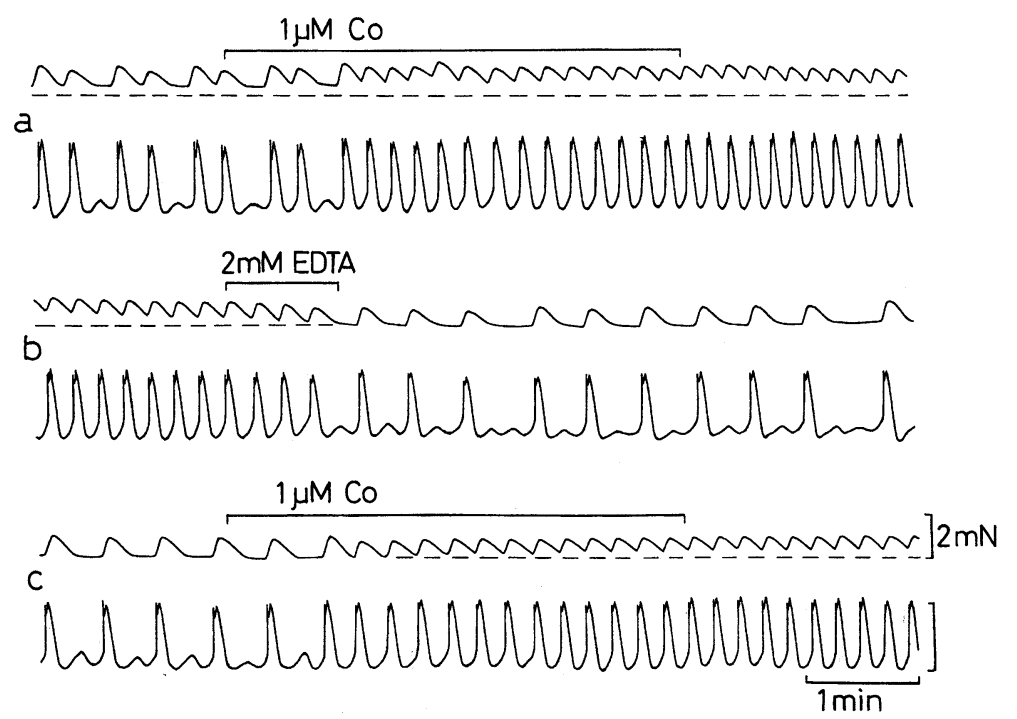

Fig. 4. Effects of $1 \mu \mathrm{M} \mathrm{Co}^{2+}$. $\mathrm{Co}^{2+}$ was applied for $4 \mathrm{~min}$ as shown by the horizontal bar on top of record (a). EDTA $(2 \mathrm{mM})$ was applied for $1 \mathrm{~min}(\mathrm{~b})$ and $\mathrm{Co}^{2+}$ was applied again (c). Continuous records; intervals between records $\mathrm{a}$ and $\mathrm{b}$, and $\mathrm{b}$ and $\mathrm{c}$ are $5 \mathrm{~min}$ and $2 \mathrm{~min}$, respectively. 

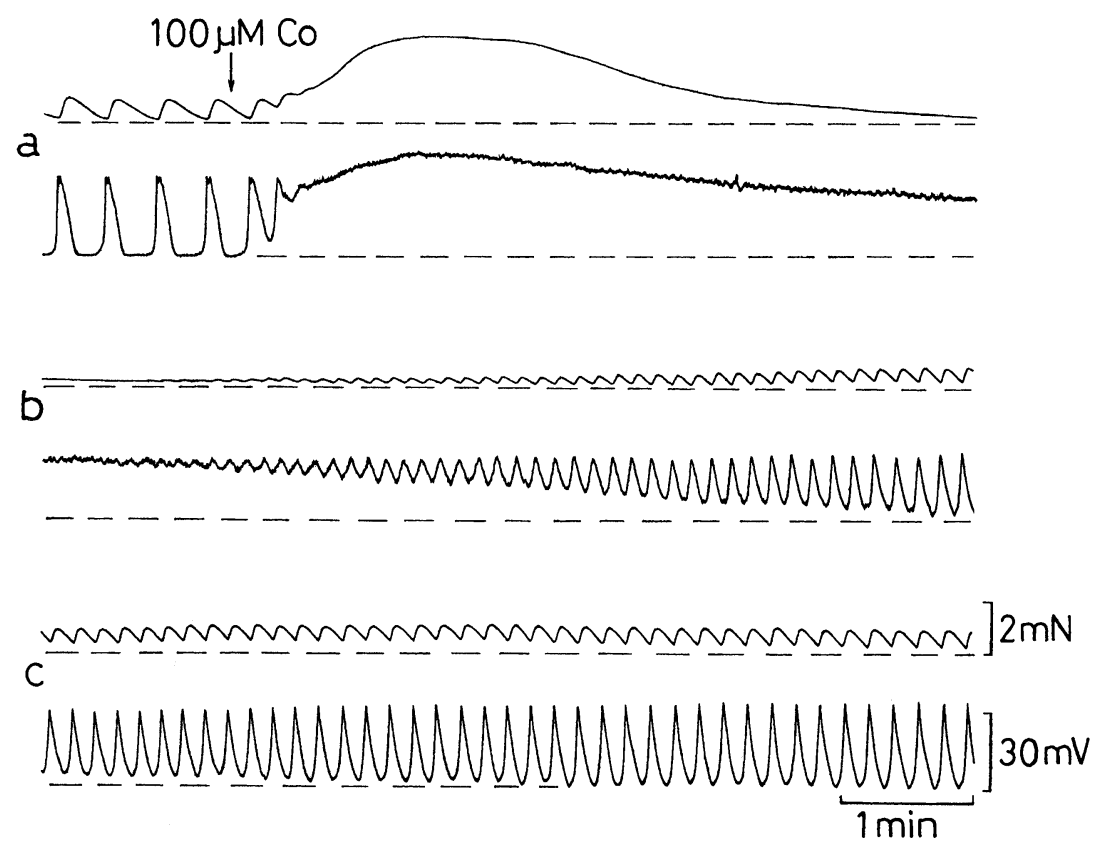

Fig. 5. An example of a strong depolarizing effect of $\mathrm{Co}^{2+}(100 \mu \mathrm{M})$ in the absence of nifedipine. Continuous recordings.

second application produced very little further effect.

\section{Effects of $\mathrm{Ca}^{2+}$ removal}

The effects of $\mathrm{Ca}^{2+}$ removal are shown in Fig. 6. $\mathrm{Ca}^{2+}$ removal slowly abolished slow wave activity, usually taking more than $5 \mathrm{~min}$, but since a steady intracellular recording was difficult in $\mathrm{Ca}^{2+}$-free solution, $\mathrm{Ca}^{2+}$ was only removed for $4 \mathrm{~min}$ in this experiment, a time sufficient to nearly abolish the contractions initiated by the slow waves. $\mathrm{Ca}^{2+}$ removal clearly decreased the rate of rise (from $40 \mathrm{mV} \mathrm{sec}^{-1}$ to $12 \mathrm{mV} \mathrm{sec}^{-1}$ ) and shortened the duration of the slow waves, but the decrease in slow wave amplitude was less significant (a). In the presence of 200 $\mu \mathrm{M} \mathrm{Co}^{2+}$ after the tissue had recovered from the initial depolarization, $\mathrm{Ca}^{2+}$ removal caused essentially the same effects as before $\mathrm{Co}^{2+}$ application, i.e., slower maximum rate of rise (from $59 \mathrm{mV} \mathrm{sec}^{-1}$ to $27 \mathrm{mV} \mathrm{sec}^{-1}$ ) and shorter duration (b). Contraction was again nearly abolished after 4 min. $10 \mathrm{~min}$ after $\mathrm{Co}^{2+}$ wash-out (c) $\mathrm{Ca}^{2+}$ removal again produced similar effects, the maximum rate of rise being reduced from $38 \mathrm{mV} \mathrm{sec}^{-1}$ to $23 \mathrm{mV} \mathrm{sec}^{-1}$.

\section{Effects of $\mathrm{Na}^{+}$removal in the presence of $\mathrm{Ni}^{2+}$ or $\mathrm{Co}^{2+}$}

Removal of $\mathrm{Na}^{+}$by substituting with NMDG produced depolarization, in the presence or absence of nifedipine (1-3 $\mu \mathrm{M}$ ) (Tomita and Pang, 1996). The amount of depolarization varied to some extent among different preparations. If the depolarization was relatively small, the main effect was to cause a prolongation of the slow waves as shown in Fig. 7a. In this tissue, after recovery following reintroduction of $\mathrm{Na}^{+}, 100 \mu \mathrm{M} \mathrm{Ni}{ }^{2+}$ was applied which produced typical transient effects on the slow waves and contraction (Fig. 7b). Between (b) and (c) in 


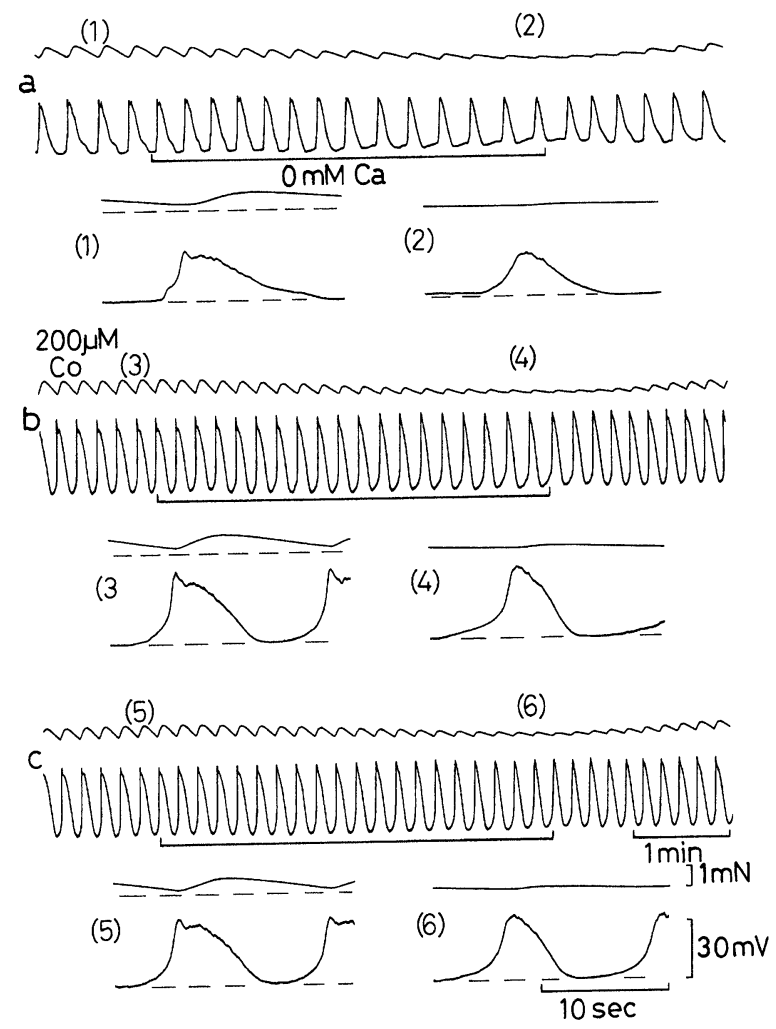

Fig. 6. Effects of $\mathrm{Ca}^{2+}$ removal before (a), during (b) and 7 min after $200 \mu \mathrm{M} \mathrm{Co}^{2+}$ pplication (c) in the presence of $1 \mu \mathrm{M}$ nifedipine. In $0 \mathrm{mM} \mathrm{Ca}^{2+}$ solution, $\mathrm{CaCl}_{2}$ was omitted and $100 \mu \mathrm{M}$ EGTA was added. Below the records at slow speed are shown slow waves recorded at an 8 times faster speed. Their number corresponds to those of the slow waves indicated in the slow records $(a, b, c)$.

Fig. $7 \mathrm{Ni}^{2+}$ was washed out, although the effects still remained so that further application of 1 $\mathrm{mM} \mathrm{Ni}^{2+}$ caused no depolarization, but slowly inhibited the slow waves. Exposure to $\mathrm{Na}^{+}$-free solution in the presence of $1 \mathrm{mM} \mathrm{Ni}^{2+}$ now restarted the slow waves (Fig. 7d).

Similar experiments of $\mathrm{Na}^{+}$removal were carried out in the presence of $3 \mathrm{mM} \mathrm{Co}^{2+}$ (Fig. 8). In the preparation shown in Fig. $8 \mathrm{Na}^{+}$removal produced a typical large depolarization which abolished the slow waves (a). Between (a) and (b), the preparation was treated with 100 $\mu \mathrm{M} \mathrm{Co}^{2+}$ for $3 \mathrm{~min}$ and $20 \mathrm{~min}$ later $3 \mathrm{mM} \mathrm{Co}^{2+}$ was applied again (b). The pretreatment with $100 \mu \mathrm{M} \mathrm{Co}{ }^{2+}$ inhibited the early depolarization normally produced by $3 \mathrm{mM} \mathrm{Co}^{2+}$ which now abolished slow waves after a transient increase in their amplitude. $\mathrm{Na}^{+}$removal in the presence of $\mathrm{Co}^{2+}$ restarted the slow waves accompanied by only a small depolarization (c).

\section{Discussion}

It seems likely that in the guinea-pig stomach, $\mathrm{Ca}^{2+}$ is the main charge carrier for producing the slow waves, because the presence of $\mathrm{Ca}^{2+}$ is necessary for slow wave activity, although the type of $\mathrm{Ca}^{2+}$ influx pathway is difficult to define. Since the maximum rate of rise 

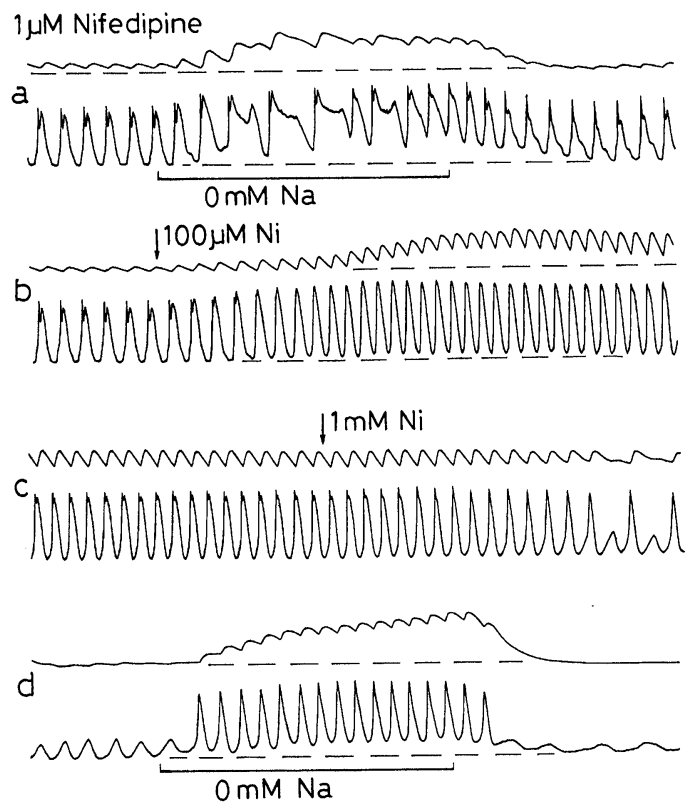

1 min after $\mathrm{Ni}$ wash-out ] $2 \mathrm{mN}$

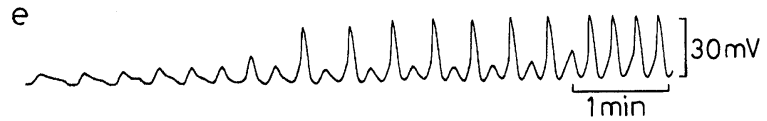

Fig. 7. Effects of $\mathrm{Na}^{+}$removal in the absence and the presence of $1 \mathrm{mM} \mathrm{Ni}^{2+}$.

After observing effects of $\mathrm{Na}^{+}$removal (substituted with NMDG) (a), $100 \mu \mathrm{M} \mathrm{Ni}^{2+}$ was added for $10 \mathrm{~min}$ (b), and $10 \mathrm{~min}$ after wash-out of $\mathrm{Ni}^{2+}, 1 \mathrm{mM} \mathrm{Ni}^{2+}$ was applied (c). $5 \mathrm{~min}$ later $\mathrm{Na}^{+}$was removed again still in the presence of $\mathrm{Ni}^{2+}(\mathrm{d})$. When $\mathrm{Ni}^{2+}$ was washed out between $\mathrm{d}$ and e, slow wave activity gradually recovered (e). Nifedipine $(1 \mu \mathrm{M})$ was present throughout.

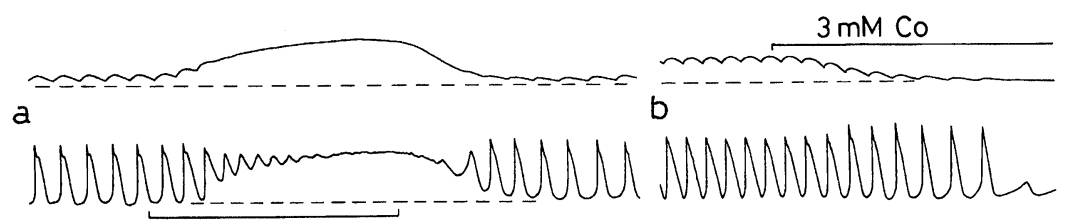

$0 \mathrm{mM} \mathrm{Na}$

$3 \mathrm{mM} \mathrm{Co}$ $2 \mathrm{mN}$

C

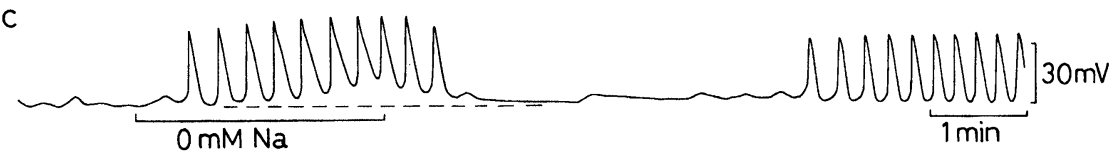

Fig. 8. Similar experiment to Fig. 7, but $3 \mathrm{mM} \mathrm{Co}^{2+}$ was used instead of $1 \mathrm{mM} \mathrm{Ni}^{2+}$. Between a and $\mathrm{b}, 100 \mu \mathrm{M} \mathrm{Co}^{2+}$ was applied for $3 \mathrm{~min}$ and $7 \mathrm{~min}$ later $3 \mathrm{mM} \mathrm{Co}^{2+}$ was applied as indicated above record (b). $\mathrm{b}$ and $\mathrm{c}$ are continuous records. Nifedipine $(1 \mu \mathrm{M})$ was present throughout the experiments. 
of the slow wave (about $50 \mathrm{mV} \mathrm{sec}{ }^{-1}$ ) is less than $1 / 100$ of a typical action potential in intestinal smooth muscle (about $7 \mathrm{~V} \mathrm{sec}^{-1}$, Tomita, 1970), a relatively small inward current would be enough to generate the depolarization if there is no significant counteracting outward current. The contribution of $\mathrm{Na}^{+}$as the charge carrier is difficult to study because of the membrane depolarization on its removal. However, since slow waves can be produced in $\mathrm{Na}^{+}$-free solution when the membrane depolarization is prevented by $\mathrm{Ni}^{2+}$ or $\mathrm{Co}^{2+}$, it is unlikely that $\mathrm{Na}^{+}$is carrying the inward current. Initiation of slow waves by $\mathrm{Na}^{+}$removal can also be demonstrated under conditions in which slow waves are abolished and membrane depolarization is prevented by phosphodiesterase inhibitors, such as theophylline (Tsugeno, Chowdhury, Pang, and Tomita, 1995). The fact that slow waves can be generated in the presence of $1 \mathrm{mM}$ $\mathrm{Ni}^{2+}$ or $3 \mathrm{mM} \mathrm{Co}^{2+}$ throws some doubt on the idea that these ions directly block the inward current pathway responsible for slow wave production. Their ability to suppress slow waves may be due mainly to inhibition of pacemaker activity rather than blockade of inward currents, but further study on this mechanism is necessary. $\mathrm{Cl}^{-}$removal (by substitution with isethionic acid) produces a relatively weak effect at least for about 5 min (unpublished observations), suggesting that $\mathrm{Cl}^{-}$effux is also not playing a major role in the depolarization of slow wave.

The slow wave in the guinea-pig gastric muscle is not significantly affected by nifedipine or nicardipine (1-3 $\mu \mathrm{M})$ even after membrane depolarization with $60 \mathrm{mM} \mathrm{K}^{+}$in the presence of the channel blockers. This differs from the slow wave in the circular muscle of the canine colon in which the slow plateau phase is inhibited by nifedipine (Ward and Sanders, 1992a, b). It is likely in the present experiment described above that the $\mathrm{L}$-type $\mathrm{Ca}^{2+}$ channels can be mostly and nearly irreversibly blocked by nifedipine since both $\mathrm{K}^{+}$contractures and the contractions elicited by the slow wave remained inhibited for more than 30 min after wash-out following $10 \mathrm{~min}$ treatment with nifedipine. This suggests that any contribution of the L-type $\mathrm{Ca}^{2+}$ channel to slow waves in the guinea-pig gastric muscle is very minor not only to the rising phase but also to the slow depolarizing phase.

$\mathrm{Ni}^{2+}$ and $\mathrm{Co}^{2+}$ have potentiating effects on slow waves in the guinea-pig gastric muscle. A similar facilitating effect on the frequency accompanied with depolarization has been reported for $100 \mu \mathrm{M} \mathrm{Mn}^{2+}$ in the same tissue and the effect was explained by displacement or release of $\mathrm{Ca}^{2+}$ from the surface membrane by $\mathrm{Mn}^{2+}$ (Sakamoto, 1985). The effects of $\mathrm{Ni}^{2+}$ differ from its effects in the canine colonic slow wave, in which only inhibitory effects have been reported (Ward and Sanders, 1992a). In the colon, a combination of nifedipine $(1 \mu \mathrm{M})$ and $\mathrm{Ni}^{2+}(40 \mu \mathrm{M})$ blocked slow wave generation. In the guinea-pig gastric muscle, these transition metal ions reduce the rate of rise at first, particularly when the membrane is depolarized, but this slowly recovers in the presence of the ions. Since $\mathrm{Ni}^{2+}$ is considered to block the $\mathrm{T}$-type $\mathrm{Ca}^{2+}$ channels at a concentration of 30-50 $\mu \mathrm{M}$ (Spedding and Paoletti, 1992 ; Kuriyama, Kitamura and Nabata, 1995), the lack of susceptibility of slow waves to $\mathrm{Ni}^{2+}(100 \mu \mathrm{M})$ is difficult to explain by the involvement of typical T-type $\mathrm{Ca}^{2+}$ channels. Contraction produced by $\mathrm{Co}^{2+}(3-$ $100 \mu \mathrm{M}$ ) has been reported for vascular smooth muscle and the presence of $\mathrm{Ca}^{2+}$ is neceassary for this contraction (Gallagher, Alade, Dominiczak and Bohr, 1994). It is rather unlikely that $\mathrm{Co}^{2+}$ and $\mathrm{Ni}^{2+}$ carry enough inward currents on their own to contribute to slow wave generation because they are quite effective at a very low concentration $(10-30 \mu \mathrm{M})$ in the presence of 
$\mathrm{Ca}^{2+}$ and because their potentiating effects continue after the ions have been washed-out. In the snail neurones $\mathrm{Co}^{2+}$ and $\mathrm{Ni}^{2+}$ have been shown to increase inward $\mathrm{Ca}^{2+}$ current (Kim and Woodruff, 1991). The effect has been explained by inhibition of outward currents by the transition metal ions, an explanation supported by the prolongation of the action potentials. Although this possibility cannot be discarded, the lack of prolongation of slow wave duration both with $\mathrm{Ni}^{2+}$ and $\mathrm{Co}^{2+}$, in contrast to the observation in the snail neurones, does not support the idea. In the guinea-pig gastric muscle, $\mathrm{Co}^{2+}$ and $\mathrm{Ni}^{2+}$ may directly increase $\mathrm{Ca}^{2+}$ influx through a pathway which is resistant to dihydropyridine channel blockers and may increase the frequency of the large square slow wave which is likely to act as the pacemaker of slow wave, probably intracellularly.

\section{References}

Gallagher, M.J., Alade, P.I., Dominiczak, A.F. and Bohr, D.F. (1994) Cobalt contraction of vascular smooth muscle is calcium dependent. J. Cardiovasc. Pharmacol. 24 : 293-297.

Huizinga, J.D. (1991) Action potentials in gastrointestinal smooth muscle. Canad. J. Physiol. Pharmacol. 69: 1133-1142.

Huizinga, J.D., Farraway, L. and Den Hertog, A. (1991) Generation of slowwave-type action potentials in canine colon smooth muscle involves a non-L-type $\mathrm{Ca}^{2+}$ conductance. $J$. Physiol. 442: 15-29.

Kim, Y.-K. and Woodruff, M.L. (1991) Cobalt-dependent potentiation of net inward current density in Helix aspersa neurones. J. Neurosci. Res. $28: 549-555$.

Kuriyama, H., Kitamura, K. and Nabata, H. (1995) Pharmacological and physiological significance of ion channels and factors that modulate them in vascular tissues. Pharmacol. Rev. 47 : $378-573$.

Ohba, M., Sakamoto, Y. and Tomita, T. (1977) Effects of sodium, potassium and calcium ions on the slow wave in the circular muscle of the guinea-pig stomach. J. Physiol. 267 : 167-180.

Sakamoto, Y. (1985) The effect of Mn on the electrical and mechanical activities in the guinea-pig stomach. Jpn. J. Physiol. 35: 853-866.

Sanders, K.M. (1992) Ionic mechanisms of electrical rhythmicity in gastrointestinal smooth muscles. Ann. Rev. Physiol. 54 : 439-453.

Spedding, M. and Paoletti, R. (1992) III. Classification of calcium channels and the sites of action of drugs modifying channel function. Pharmacol. Rev. 44:363-376.

Taylor, G.S., Daniel, E.E. and Tomita, T. (1976) Origin and mechanism of intestinal slow waves. In: Proceedings of the Vth International Gastrointestinal Motility, ed. by Vantrappen, G., Typoff Press, Herentals, Belgium, pp. 102-106.

Tomita, T. (1970) Electrical properties of mammalian smooth muscle. In : Smooth Muscle, ed. by Bülbring, E., Brading, A.F., Jones, A.W. and Tomita, T., Edward Arnold, London, pp. 127-156.

Tomita, T. (1981) Electrical activity (spikes and slow waves) in gastrointestinal smooth muscle. In: Smooth Muscle: An Assessment of Current Knowledge, ed. by Bülbring, E., Brading, A. F., Jones, A.W. and Tomita, T., Edward Arnold, London, pp. 127-156.

Tomita, T. and Pang, Y.-W. (1996) Membrane depolarization caused by sodium removal in the circular muscle of guinea-pig gastric antrum. In: Smooth Muscle Excitation, ed. by Bolton, T.B. and Tomita, T., Academic Press, London, pp. 437-477.

Tsien, R.W and Tsien, R.Y. (1990) Calcium channels, stores, and oscillations. Ann. Rev. Cell Biol. 6: 715-760.

Tsugeno, M., Huang, S.-M., Pang, Y.-W., Chowdhury, J.U. and Tomita, T. (1995) Effects of phos- 
phodiesterase inhibitors on spontaneous electrical activity (slow waves) in the guinea-pig gastric muscle. J. Physiol. 485 : 493-502.

Ward, S.M. and Sanders, K.M. (1992a) Dependence of electrical slow waves of canine colonic smooth muscle on calcium gradient. J. Physiol. 455 : 307-319.

Ward, S.M. and Sanders, K.M. (1992b) Upstroke component of electrical slow waves in canine colonic smooth muscle due to nifedipine-resistant calcium current. J. Physiol. 455 : 321-337.

(Received August 25, 1998 : Accepted October 12, 1998) 